\title{
浅议水利工程防洪措施
}

荆文文

白城市洮儿河灌区建设管理局

DOI:10.32629/hwr.v4i4.2901

[摘 要] 水利工程是指为了控制、调节和利用自然界的地面水和地下水, 以达到除害兴利的目的而兴建的各种工程。水利工程按其服务对象可 以分为防洪工程(堤防、水库、蓄滞分洪区、涵闸、排水工程等)、农田水利工程(灌溉工程)、水力发电工程、航运及城市供水、排水工程。文 章详细介绍了水利工程的防洪措施。

[关键词] 水利工程; 防洪措施; 系统

水利工程防洪措施是指利用水利工程拦蓄调节洪量、削减洪峰或 分洪、滞洪等, 以改变洪水天然运动状况, 达到控制洪水、减少损失的 目的。常用的水利工程包括河道堤防、水库、涵闸、蓄滞分洪区、排 水工程等。

\section{1 修筑堤防,约束水流}

河道是渲泄洪水的通道。提高河道泄洪能力是平原地区防洪的基本措 施, 修筑堤防是这一措施的重要组成部分。堤防在防洪中的作用是：约束 水流, 提高河道泄洪排水能力; 限制洪水泛滥, 保护两岸工农业生产和人民 生命财产安全; 抗御风浪和海潮, 防止风暴潮侵袭陆地。

堤防的建设, 一般都与河道整治密切结合。例如为了扩大河道泄洪能 力, 除加高培厚堤防还要采取疏浚河道、裁弯取直、改建退建以及及时清 除河道内的阻水障碍物等措施。为了巩固堤防, 需要修建河道流势的控导 工程和险工段的防护工程等。

\section{2 兴建水库, 调蓄洪水}

水库一般是指利用山谷建造拦河坝, 拦截径流, 抬高水位, 在坝上形成 蓄水体, 即人工湖泊。在平原地区, 利用湖泊、洼地、河道, 通过修筑围堤 和控制闸等建筑物, 形成平原水库, 许多河道受洪水的严重威胁, 如不修建 控制性水库是无法解决的。不少中小河流及其下游的城市, 也必须有水库 的调节控制, 才能保证防洪安全。

水库的防洪一般要兼顾上下游。为了水库上游周边的工农业生产发展 及人民生活, 库内蓄水高度要加以限制; 水库向下游泄洪量的大小则应考 虑下游河道的安全。在一个流域或地区内如有多个水库, 可以通过联合运 用, 发挥干支流错锋、补偿调节的作用。水库的任务一般除了防洪还要兴 利, 前者要求在洪水到来前能腾出较充分的库容以接纳洪水, 后者则要求 水库经常保持较多的蓄水量。因此, 水库在防洪时, 既要兼顾上下游的要求, 又要拦蓄部分洪水以转化为可利用的水资源供非汛期使用, 这就要制定出 合理的水库工程控制运用方案。在方案实施时还要依靠及时、准确的气象、 水文情报与预报, 作为决策的依据。

\section{3 建造水闸,控制洪水}

水闸是一种低水头水工建筑物, 它的作用既能挡水, 又能泄水, 按其防 洪排涝作用可分为:

（1）分洪闸。它是分泄河道洪水的水闸。当河道上游出现的洪峰流量 超过下游河道安全泄量时, 为保护下游重要城镇及农田免遭洪灾, 将部分 洪水通过分洪闸泄入预定的湖泊洼地 (蓄洪区或滞洪区), 也可将洪水分泄
入水位较低的邻近河流。

(2) 挡潮闸。它是设于感潮河流的河口防止海潮倒灌的水闸。涨潮时, 潮水位高于河水位, 关闸挡潮; 汛期退潮时, 潮水位低于河水位, 开闸排水。 枯水期闸门关闭, 既挡潮水, 又兼蓄淡水。

（3）节制闸。它是调节上游水位, 控制下泄流量的水闸。天然河道的节 制闸也称为拦河闸。枯水期, 关闭闸门抬高上游水位, 以满足兴利要求; 洪 水期, 开闸泄洪, 使上游洪水位不超过防洪限制水位, 同时控制下泄洪水流 量, 使其不超过下游河道的安全泄量。

(4) 排水闸。它是排泄洪涝水的水闸,一般是指洪涝地区向江河排水的 水闸。当外河水位高于堤内水位时, 关闸挡水, 防止河水倒灌; 当堤外江河 水位低于堤内洪涝水位, 开闸排水, 减免洪涝灾害损失。

\section{4 利用蓄滞、分洪区, 减轻河道行洪压力}

大江大河中下游两岸常有湖泊洼地与江河相通, 洪水期江河洪水漫溢, 这些湖洼起了自然滞蓄洪水、降低河道水位、减轻洪水对下游威胁的作用。 为了更有效地利用沿岸湖洼调蓄稀遇洪水的作用, 现在许多流域都有计划 地用围堤将大部分沿岸湖洼与河道分开, 建成为蓄滞、分洪区。在水位到 达一定高度时采取自流分洪、水闸控制分洪或人为开口分洪等措施, 以临 时蓄、滞洪水, 减轻河道的行洪压力。

由于蓄滞洪区、分洪区一般使用机会不多, 随着人口的增长和经济的 发展, 蓄滞洪区、分洪区内居民日益增多, 这就造成了需要分洪时的困难和 巨大损失。因此, 尚需要有一系列的非工程措施与之配合, 才能使蓄滞洪 区、分洪区的作用得以发挥。

\section{5 建立排水系统}

排除洪涝积水排涝工程有自排工程和机电排水工程两类。

(1) 自排工程。自排工程也就是自流排涝工程, 它主要为河道及排水 沟。可选择地势较低的江河、湖泊作为自排的容泄区。

(2) 机电排水工程。洪涝积水无法向容泄区自排时, 就需要在适当地点 修建排水站, 利用机电进行排水。沿江沿湖圩区, 在遇到雨涝时, 一般都采 用自排与机电排相结合进行排涝。

\section{[参考文献]}

[1]王仁钟,章为民,蔡跃波,等.我国水利工程建设与管理[J].水利水电 技术,2001(01):33.

[2]朱涛.开创水利建设与管理工作新局面[J].中国水利报,2003(3)164. [3]徐俊仁.加强水利建设管理的思路和措施[J]. 江苏水利,2001(5):76. 